\title{
Correction to: Application of a Novel 'Make and Test in Parallel' Strategy to Investigate the Effect of Formulation on the Pharmacokinetics of GDC-08 I 0 in Healthy Subjects
}

\author{
Sravanthi Cheeti ${ }^{\prime}$ • Hao Helen Hou' • Eric Nelson ' - Helen Walker ${ }^{2}$ • Buyun Chen ' \\ Roland Morley' • Mary Gates' • Luna Musib' • Sandhya Girish' • Srikumar Sahasranaman ' \\ Lichuan Liu' \\ Published online: 26 October 2018 \\ (C) Springer Science+Business Media, LLC, part of Springer Nature 2018
}

\section{Correction to: Pharm Res https://doi.org// 0.1007/s I 1095-0 I 8-25 I6-0}

The Publisher regrets the typesetting mistake of retaining incorrect text in the Figure 1 caption. The correct text for the caption is "Molecular Structure of GDG-0810 NMG Salt". The original article has been corrected.

The online version of the original article can be found at https://doi.org/l 0 . |007/s | |095-0 | 8-2516-0

Sravanthi Cheeti

cheeti.sravanthi@gene.com

Genentech, Inc., I DNA Way, MS\# 463A, Genentech, South San

Francisco, California 94080, USA

2 Quotient Sciences, Mere Way, Ruddington, Nottingham, UK 